Rok XV (2020) | 2 (30)|S. 273-296

https://doi.org/10.12797/LV.15.2020.30.20

Bronisława Ligara ๑

Uniwersytet Jagielloński, Kraków

bronislawa.ligara@uj.edu.pl

\title{
METAJĘZYKOWE DZIAŁANIA NA TEKŚCIE OSOBY DWUJĘZYCZNEJ
}

Słowa klucze: działania metajęzykowe, bilingwizm/dwujęzyczność, tłumaczenie, mediacja językowa, Zygmunt Krasiński

Keywords: metalinguistic actions, bilingualism, translation, linguistic mediation, Zygmunt Krasiński Mots clés: opérations métalinguistiques, bilinguisme, traduction, médiation linguistique, Zygmunt Krasiński

\section{Wprowadzenie}

W artykule mowa będzie o działaniach językowych, jakich dokonuje osoba dwujęzyczna, przenosząc zdarzenie komunikacyjne zaistniałe w jednym z jej języków (dalej J1) do przestrzeni drugiego jej języka (dalej J2) poprzez transpozycję tekstu wyjściowego mówionego, nieutrwalonego, a jedynie zapamiętanego na tekst docelowy napisany. Ten ostatni jest zatem produktem dwóch operacji: czynności tłumaczenia $\mathrm{z}$ równoczesnym przekształceniem pierwotnego wykonania oralnego na zapis. Może ich jednocześnie dokonać jedynie wybitny bilingwista - współtwórca i aktywny świadek zdarzenia komunikacyjnego będącego przedmiotem translacji. Takie właśnie działania na tekście odsłania zachowana dwujęzyczna spuścizna Zygmunta Krasińskiego i z tego względu stanowi ona szczególnie interesujący obiekt badawczy dla badań bilingwizmu indywidualnego polsko-obcego ${ }^{1}$. Badanie jego

1 Dwujęzyczność traktuję jako przypadek wielojęzyczności, nie przeciwstawiam jej więc jednojęzyczności, jak to ma miejsce u Jacques’a Derridy (1996). 
praktyki dwujęzycznej w zakresie zapowiedzianej w tytule problematyki zostanie przeprowadzone jako studium przypadku (case study).

Teren obserwacji stanowią dwa posłuchania - we współczesnej nomenklaturze audiencje - prywatne w cztery oczy, udzielone Zygmuntowi Krasińskiemu przez cesarza Napoleona III w 1857 r. oraz w 1858 r. Realizacje językowe obu zdarzeń komunikacyjnych przy udziale głównie języka francuskiego, kodu wspólnego dla obu rozmówców ${ }^{2}$, miały postać prymarnie mówioną, właściwą gatunkowi, w którym powstały; z racji zaś tego, iż były to posłuchania ściśle poufne, powinny były pozostać nieutrwalone bez możliwości dalszej dystrybucji. Ich werbalny kształt oraz zawartość treściowa mogły ewentualnie zostać w głowach uczestników wymiany konwersacyjnej jedynie zapamiętane, ze wszystkimi ograniczeniami fizycznymi warunkującymi w sposób naturalny przechowanie w pamięci dłuższych tekstów in extenso raz jeden tylko wypowiedzianych/wysłuchanych.

Krasiński nie dotrzymał warunków wstępnych, bez których do wymiany konwersacyjnej między nim a Napoleonem III, zaktualizowanej w gatunku audiencji ściśle poufnej, w ogóle by nie doszło. Przymus moralny ścisłej poufności należy niejako do normy gatunku, jakim jest posłuchanie ściśle tajne. Dokonał zatem jej transgresji. Ale dzięki tej transgresji przyszła polska wspólnota narodowa po śmierci Krasińskiego (nastąpiła w 1859 r.) otrzymała w 1912 r. ${ }^{3}$ materialną manifestację dyskursu politycznego toczonego w połowie XIX w. w przestrzeni europejskiej przez ówczesne elity polityczne w osobie cesarza Napoleona III, z głosem danym przedstawicielowi polskiej wspólnoty narodowej wypowiadającemu się w jej imieniu, w świadomości tych pierwszych prawie nieobecnej, bo nieistniejącej jako podmiot polityczny ${ }^{4}$.

$\mathrm{Na}$ ów dyskurs polityczny z udziałem Zygmunta Krasińskiego składają się dwa teksty niezwykłej wagi: jego translacje obu audiencji na język polski. Są to translacje szczególnego rodzaju, gdyż wymykają się gatunkowemu przyporządkowaniu do tłumaczenia bądź przekładu w rozumieniu przekładoznawstwa: nie są ani tłumaczeniem ustnym (symultanicznym czy konsekutywnym), ani też pisemnym sensu stricto, tzn. przekładem tekstu wyjściowego napisanego na tekst docelowy również pisany. Stanowią hybrydę: z pierwszym typem tłumaczenia łączy je sposób odbierania tekstu wyjściowego (dalej TW), który został jeden raz wypowiedziany/wysłuchany, z drugim zaś sposób przekazywania tekstu docelowego (dalej TD) - postać zapisu. Natomiast od przekładu pisemnego translacje audiencji odróżnia to, że tłu-

2 Zygmunt Krasiński dokonał też w toku audiencji przełączania kodu (CS) z francuskiego na angielski, niemiecki i łacinę, zob. punkt 3.5 artykułu.

3 Postuchania pozostawały w rękopisie do 1912 r., kiedy to zostały opublikowane po raz pierwszy przez Jana Czubka.

4 Odwołuję się tutaj do typologii dyskursu autorstwa Bożeny Witosz, według kryterium instytucjonalnego oraz powiązanego z nim kryterium tematu, inaczej odniesień przedmiotowych (Witosz 2016: 22-29): dyskurs polityczny jest zarazem instytucjonalny, bo dotyczy domeny społecznej i ma za temat politykę. W kwestii rozumienia terminu dyskurs zob. Ligara 2018: 260. 
macz nie mógł odczytywać tekstu wyjściowego wielokrotnie; taka sytuacja sprzyjała dokonywaniu tłumaczenia poprzez zapisywanie go jako działania, przy użyciu strategii mediacji (między)językowej, o której poniżej.

Są one tekstem docelowym czynności tłumaczenia napisanym, który z tej racji może być poddany z jednej strony analizie traduktologicznej badającej związek między TW a TD, z drugiej zaś analizie tekstologicznej pod kątem językowym, gatunkowym oraz dyskursywnym ${ }^{5}$. Gdy idzie o tę drugą, odwołuję się do założenia badawczego semantyki tekstów François Rastiera, że każdy tekst - wytwór o określonej postaci językowej - wypływa z danego gatunku, gatunek zaś odnosi się do określonego dyskursu (Rastier 1996: 4-6). Analiza traduktologiczna tekstu poszukiwać zatem będzie, jak badane teksty docelowe odpowiadają normom języka tłumaczenia (tu J2 - polskiego), a także spełniają adekwatność względem oryginału mówionego, gdy idzie o normę gatunkową, czyli adekwatność co do interakcji mikrosocjologicznych, oraz gdy idzie o normy dyskursywne, czyli adekwatność co do struktur argumentacyjnych.

Podstawę metodologiczną prezentowanych badań stanowi pojęcie działań na tekście sformułowane na gruncie tekstologii przez Jerzego Bartmińskiego i Stanisławę Niebrzegowską-Bartmińską (Bartmiński, Niebrzegowska-Bartmińska 2009: 312-228) - w artykule odwołuję się do transformacji i parafrazy. Pojęcie działań na tekście uszczegółowił Jerzy Święch w odniesieniu do tłumaczenia poezji (Święch 2015: 12-41).

Następnie, ponieważ literatura przedmiotu uznaje tłumaczenie za komunikację meta, czyli komunikację drugiego stopnia, tzn. biorącą za swój obiekt jej pierwszy stopień (oryginał) (Ladmiral 1994: 144), przywołane w tytule działania osoby dwujęzycznej wpisują się w pojęcie operacji metajęzykowej w ujęciu Romana Jakobsona. Zasadza się ona na interpretacji jednego znaku językowego przez inne znaki (Jakobson 1989: 387), a tłumaczenie jest właśnie interpretacją znaków J1 (użytych w TW) przez znaki J2 (wybrane przez tłumacza w TD).

Podejście do tłumaczenia $\mathrm{w}$ terminach interpretacji oryginału przez tłumacza wiąże się z kolei z perspektywą hermeneutyczną badań przekładoznawczych, wprowadzoną przez George'a Steinera m.in. w studium Po wieży Babel. Aspekty języka i przekładu (2018). Jego model hermeneutycznego aktu przekładu obejmuje cztery etapy translacji nazwane jako: „wstępne zaufanie - agresja - wchłonięcie - wzajemność lub restytucja" (ibid.: 21). W przypadku materiału, jaki stanowią Posłuchania, dla analizy traduktologicznej szczególnie przydatne okazuje się uświadomienie sobie przez badacza etapów „agresji” oraz „wchłonięcia”. A to dlatego, że Posłuchania nie wydają się finalnie dopracowanym przekładem, w rozumieniu tłumaczenia

5 Ponieważ tekst wyjściowy jako mówiony nie jest materialnie dostępny, analiza przekładoznawcza nie może w przypadku Postuchań objąć porównywania integralnych tekstów oryginalnych i ich przekładów (Koller 2009: 153). 
pisemnego ${ }^{6}$. Nie on zresztą zdaje się celem Krasińskiego. Model Steinera daje narzędzie badawcze do prześledzenia procesu wyłaniania się tekstu, tu wielojęzycznego, w mediacji międzyjęzykowej, a taki właśnie ogląd Posłuchań jest hipotezą badawczą niniejszego artykułu?

Przywołany w tytule artykułu przedmiot badań wymaga jeszcze doprecyzowania, iż oba Posłuchania stanowią w obrębie badań przekładoznawstwa dyskurs II stopnia: teksty te są działaniami tłumacza na dyskursie I stopnia - werbalnym kształcie dwóch dialogów twarzą w twarz z udziałem cesarza Napoleona III i Zygmunta Krasińskiego, bez udziału osób trzecich ${ }^{8}$. Bez uświadomienia sobie tego oczywistego faktu czytelnik Pism filozoficznych i politycznych Zygmunta Krasińskiego $(1912,1999)$ w pierwszym oglądzie, np. choćby ze spisu treści, może odnieść mylne wrażenie, iż Pierwsze postuchanie u Napoleona III (w 1857 r.) (Pierwsze 1857: 271-275) oraz Drugie postuchanie u Napoleona III (w 1858 r.) (Drugie 1858: 281-287) są tekstami pierwotnie polskimi (dyskursem I stopnia), nie zaś wtórnymi, ponieważ w nadmienionym tomie ( $w$ obu wydaniach) nie ma oryginałów francuskich. Same zresztą tytuły obu tekstów nie są autorstwa Krasińskiego, a zostały dodane przez Jana Czubka, wydawcę (Pisma Zygmunta Krasińskiego. Wydanie jubileuszowe) w 1912 r. Na opublikowany dyskurs II stopnia składa się tłumaczenie wypowiedzi cudzych - Napoleona III oraz autotłumaczenie replik własnych Krasińskiego.

Dyskurs zaś, definiowany jako działanie językowe w kontekście (Dąmbska-Prokop 2010: 68), poszerza pole analizy tekstu o warunki jego wytworzenia i warunki jego odbioru/interpretacji (Adam 1999: 39) - kluczowe dla tłumacza, gdy idzie zarówno o zrozumienie oryginału, jak i dokonywanie translacyjnych wyborów. To właśnie kontekst zewnętrznojęzykowy, tj. sytuacja komunikacyjna, wymaga działania językowego określonego typu, a nim rządzą reguły społeczne i kulturowe w postaci gatunku, w którym tekst zostaje zrealizowany (ibid.: 36-40; Charaudeau, Maingueneau 2002: 134-136). Oba wyżej nadmienione działania translatorskie są zatem pochodnymi gatunku audiencji, w którym powstał dyskurs I stopnia, ściśle do tego ostatniego przynależącymi.

\section{0d zdarzenia komunikacyjnego w J1 do dyskursu II stopnia w J2}

Analiza przekładoznawcza implikuje konieczność badania Posłuchań jako dyskursu II stopnia, to znaczy w relacji do dyskursu I stopnia, oryginału. Ponieważ oryginał został zrealizowany w gatunku mówionym i jego kształt werbalny został jedynie

6 Zob. definicję tłumaczenia pisemnego w: Dąmbska-Prokop 2010: 271.

7 Zob. Ligara 2014b: 164-167.

8 O tłumaczeniu jako komunikacji II stopnia - metakomunikacji - pisze Jean-René Ladmiral (1994: 144); tłumaczenie jako dyskurs II stopnia przedstawia Barbara Walkiewicz (2015). 
„zatrzymany” w pamięci uczestnika audiencji - późniejszego nadawcy dyskursu II stopnia - badacz ma do dyskursu I stopnia bardzo ograniczony dostęp. To znaczy: może zrekonstruować jedynie wymiar gatunkowy pierwotnego tekstu mówionego oraz wiążące się z gatunkiem warunki socjokulturowe stanowiące kontekst zewnętrznojęzykowy, w którym zdarzenia komunikacyjne powstały. Natomiast tekstualizacja oryginału jest możliwa tylko w niewielkim stopniu, jedynie jako elementy J1 przeniesione przez Krasińskiego do mowy dwujęzycznej, do której się uciekał, tłumacząc dyskurs II stopnia (zob. punkt 3).

Wymiar gatunkowy i wymiar zewnętrznojęzykowy audiencji miały istotny wpływ na ich kształt werbalny: nie tylko uwarunkowały, co oczywiste, powstanie tekstu pierwotnego, ale też ukierunkowały interpretację sensów konstruowanych przez nadawców audiencji, będących następnie obiektem translacji. Krasiński był kreatorem obu działań: wytworzenia zarówno dyskursu I stopnia, jak i dyskursu II stopnia. Jako równorzędny pod względem społecznym i kulturowym partner wymiany konwersacyjnej współtworzył tekst mówiony, a następnie z racji swojej kompetencji dwujęzycznej dokonał całości jego tłumaczenia.

Gatunek audiencji, w którym powstał dyskurs I stopnia, jest gatunkiem dialogu; jako poufny dialog bez jakichkolwiek świadków audiencja dawała „możliwość autentycznego, samo przez się zrozumiałego porozumiewania się" (Bachtin 1986: 283) cesarza Napoleona III i Zygmunta Krasińskiego. Obaj byli Europejczykami należącymi do ówczesnej elity intelektualnej, Napoleon III przede wszystkim politycznej. Porozumiewali się wspólnym kodem językowym i kulturowym, gdyż Krasiński był wybitnym bilingwistą polskim i francuskim; obaj znali inne języki, jak angielski, niemiecki i łacina, których elementy w postaci przełączenia kodów (code switching, dalej CS) przeniósł Krasiński do tłumaczonego dyskursu II stopnia ${ }^{9}$. Natomiast na poziomie instytucjonalnym ich status nie był równorzędny - relacja między partnerami audiencji wynikała $z$ pełnionych przez nich funkcji społecznych w przestrzeni politycznej. Napoleon III jako cesarz Francuzów reprezentował jeden z najważniejszych ośrodków władzy w Europie, natomiast Krasiński był przedstawicielem narodu polskiego bez własnego państwa, ale traktowany był przez rozmówcę jako jego reprezentatywny i miarodajny głos. Gatunek audiencji oraz hierarchiczna pozycja rozmówców narzucają wysoki stopień formalności organizacji tekstu mówionego: Krasiński był osobą proszącą o audiencje ${ }^{10}$, Napoleon III zaś z pozycji władzy ich udzielającą; to on rozpoczynał rozmowę i ją kończył skonwencjonalizowanymi formułami i gestami, jak „Charmé de faire votre connaissance” (zob. punkt 3.1., (3)), „Miło mi, żem poznał pana hrabiego” (Pierwsze 1857: 275); „Mam nadzieję, że przed

\footnotetext{
9 O wielojęzyczności Napoleona III pisze André Maurois (1947: 353).

10 O pierwszą audiencję (w 1857 r.) zabiegał sam Krasiński, na drugą natomiast (w 1858 r.) zawezwał go sam Napoleon III (Hertz 1999: 334-334, 339).
} 
moim wyjazdem stąd jeszcze się zobaczymy. Ścisnął mi rękę [...]” (Drugie 1858: 287). W pierwszej audiencji był też przede wszystkim nadawcą:

Po trzech kwadransach lub godzinie rozmowy sam na sam, podczas której sam prawie ciągle przemawiał [...] (Pierwsze 1857: 275, wyróżnienie - B.L.),

Krasiński zaś przeważnie słuchaczem:

[Przeszłej wiosny 1857 r. ] przez cały czas [Napoleon III] mówił z rzadką płynnością o dziejach wojny i losach Polski. Ledwom mógł kilka słów śród jego własnych wcisnąć (Drugie 1858: 287, wyróżnienie - B.L.).

Natomiast w drugiej audiencji role się odwróciły - Napoleon III był głównie słuchaczem, pozyskującym od rozmówcy nieznaną sobie wcześniej wiedzę, np.:

Tu zapytał się, co to za diecezja, co to za grecy-unici. Znać wcale a wcale z tą kwestią nie obznajmion. Pokrótce opowiedziałem mu, jak cztery miliony unickiego ludu najokropniejszymi gwałty cesarz Mikołaj przywiódł na Litwie do schizmy [...] (ibid.: 285, wyróżnienie - B.L.),

i poszukującym drogą argumentacji prawdy w obszarze ówczesnej polityki:

Tą razą zaś przez pół godziny czy trzy kwadranse mnie dał ciągle prawie mówić (ibid.: 287).

Rama empiryczna dyskursu I stopnia daje się zrekonstruować z paratekstu umieszczonego przez tłumacza $\mathrm{w}$ dyskursie II stopnia oraz $\mathrm{z}$ informacji wpisanych w tekst: pierwsza audiencja miała miejsce 4 kwietnia 1857 r. o godz. „3-ej z południa” w pałacu Tuileries (w Paryżu), trwała trzy kwadranse lub godzinę (Pierwsze 1857: 271, 275); druga, 20 lipca 1858 r., w Plombières - pół godziny czy trzy kwadranse (Drugie 1858: 281, 287). Pierwszą audiencję opatrzył Krasiński nazwą gatunkową: „rozmowa sam na sam" (Pierwsze 1857: 275). Oba zdarzenia komunikacyjne były zresztą drugim i trzecim ogniwem w zespole wypowiedzi tworzących dyskurs polityczny zapoczątkowany przez Krasińskiego w 1854 r. jego Mémoire à l'empereur Napoléon III, w którym przedstawił tragiczne położenie Polaków pod trzema zaborami. Temat obu audiencji dotyczył również sprawy polskiej, tzw. la cause polonaise, był ściśle związany z ówczesnymi wydarzeniami politycznymi i sytuacją Polski w ich kontekście: kongresem państw europejskich po ukończonej wojnie wschodniej i następnym kongresem do załatwienia sprawy włoskiej - dążeń do zjednoczenia Włoch (Hertz 1999: 334-335). W przypadku obu audiencji rama dialogu z wpisaną weń naprzemiennością ról nadawcy i odbiorcy sprawiała, że sensy wypowiedzi składających się na całość dyskursu nie były z góry dane, a wypracowywane, a nawet negocjowane, gdy okazywały się konfliktowe, w interakcji werbalnej między partnerami rozmowy (Baylon, Mignot 2002: 187-188) - to w niej, w autentycznym porozumiewaniu się, poprzez wypracowanie, ustalanie sensów urzeczywistniał się cel audiencji: poznanie 
przez Napoleona III położenia Polaków pod rządami rosyjskim, pruskim i austriackim oraz argumentacja, ze strony Krasińskiego na rzecz sprawy polskiej, ze strony zaś Napoleona III za niewywoływaniem konfliktu z Rosją.

Utrwalając oba zdarzenia mówione na piśmie w dyskursie II stopnia, Krasiński dokonał szeregu działań tekstotwórczych. Mianowicie skopiował właściwą gatunkowi organizację tekstu; poszczególne repliki dialogów wyodrębnił deiksą: On, Ja (Pierwsze 1857) oraz znakiem diakrytycznym pauzy (Drugie 1858) czy też formułami wprowadzającymi oratio recta, głównie z verbum dicendi: „Wtedy odezwał się: [...]” (ibid.: 283); „Na to ja: [...]” (ibid.). Dokonywał też przeformułowań - parafraz replik na mowę zależną czy też kombinację mowy zależnej z mową niezależną. Jest ich niewiele: pięć przeformułowań w Pierwszym postuchaniu oraz siedem w Drugim postuchaniu, np.:

Ścisnął mi rękę, a gdym odchodził ku drzwiom, którymim był wszedł przyprowadzon przez generała Béville, odwołał mię mówiąc, [oratio obliqua - B.L.] że trafię na labirynt korytarzy, i ku innym poszedłszy, sam mi je otworzył i nimi wypuścił: [oratio recta - B.L.] „Tędy prostsza droga” (ibid.: 287, wyróżnienie - B.L.).

Implicytny kontekst zewnętrznojęzykowy uczynił eksplicytnym - zwerbalizował informacje o czasie i miejscu obu audiencji, okoliczności, jak do nich doszło, charakterystykę rozmówcy udzielającego mu audiencji: jego wygląd, ubranie, sposób bycia ${ }^{11}$. Kontekstem tym oprawił oba dialogi, tworząc w ten sposób dwa teksty tłumaczące: dwie „całości” semantyczne, „mające swój początek i koniec i przekazujące informację skończoną z punktu widzenia ich nadawcy" (tu: tłumacza) (Mayenowa 1979: 252).

Dyskurs II stopnia był w znacznej mierze zanurzony w kontekście dyskursu I stopnia: między audiencjami a ich zapisem w polskim materiale językowym nie zaszło znaczące odsunięcie czasowe; dokładność i szczegółowość spisanych rozmów pozwalają domniemywać, że tłumaczenia dokonał Krasiński tuż po audiencjach, w czasie, kiedy ich kształt werbalny miał całkowicie zarejestrowany w pamięci (Hertz 1999: 334, 338). To pamięć była jedynym nośnikiem tekstu mówionego, tego usłyszanego i tego wypowiedzianego przez bilingwistę-tłumacza. Dzięki swojej kompetencji dwujęzycznej, tj. współzamieszkiwaniu w jego umyśle dwóch systemów językowych, Krasiński w pamięci przechodził z J1, francuskiego, na J2, polski, i, dokonując również w pamięci operacji międzyjęzykowych, wytworzył tłumaczący (bo w J2) zapis oryginału mówionego (w J1).

11 Krasiński dodaje komentarz, że Napoleon III dostosował swój ubiór do rozmówcy (tj. Krasińskiego), nie chcąc podkreślać swej wyższej pozycji politycznej: „Czarny ubiór od stóp do głów; na fraku gwiazda brylantowa, wpół zakryta. Postać szlachetna, raczej arystokratyczna, raczej wielkiego pana niż monarchy, lecz znać było, że sam chciał tak wyglądać w tej chwili [...]" (Pierwsze 1857: 271, wyróżnienie - B.L.). 
Kluczowym czynnikiem warunkującym obie bliskie sobie czasowo operacje zapamiętywania/tłumaczenia tekstu mówionego był zatem bilingwizm Krasińskiego. Zarówno język francuski, jak i polski były jego językami pierwszymi, dokonywał więc operacji translacji z jednego swojego pierwszego języka (francuskiego) na drugi swój pierwszy język (polski) (Ligara 2015). Był nadto w obu sytuacjach komunikacyjnych i naocznym świadkiem - odbiorcą wypowiedzi Napoleona III - i współtwórcą - jednym $\mathrm{z}$ dwóch nadawców tekstu wyjściowego w J1. Zrozumienie więc tekstu pierwotnego tak kompetentne, jak przez rodzimego użytkownika języka francuskiego, czyli „wstępne zaufanie” - pierwszy etap modelu hermeneutycznego aktu przekładu (Steiner 2018: 371) - nastąpiło u Krasińskiego w naturalnej dla niego sytuacji dwujęzyczności.

Cel, dla którego Krasiński wytworzył dyskurs II stopnia, wynikał z potrzeby materialnego utrwalenia wcześniejszego dyskursu mówionego, było nim uchronienie go przed zniszczeniem - wbrew temu, że miał pozostać ulotny (Ricoeur 2003: 424-425). Był on jednak dla sprawy polskiej na tyle ważny, że Krasiński, z pozycji obywatela, naruszył normę kulturową audiencji poufnej. Ważny był zaś dlatego, że obie audiencje stanowiły autentyczną, swobodną wymianę myśli między partnerami kompetentnymi w materii aktualnej polityki i, co dla Krasińskiego było najistotniejsze, zawierały punkt widzenia Francji, mocarstwa europejskiego, na sytuację Polski w ówczesnym układzie sił w Europie lat 1857 i 1858.

Od tłumaczenia dyskursu mówionego tej wagi politycznej oczekuje się, by było ono możliwie najbardziej wierne oryginałowi, przecież ulotnemu. Jest uprawnione przyjąć, że Krasiński, podmiot moralny i od strony językowej osoba doskonale dwujęzyczna, w zapisie tłumaczącym dokonywanym w J2 odtworzył tak dokładnie, jak mu pamięć pozwalała, trzy łączące się ze sobą wymiary mówionego tekstu wyjściowego: interakcje-repliki tworzące obie rozmowy, a więc jego wymiar gatunkowy, struktury argumentacyjne zawarte w replikach - jego wymiar dyskursywny, oraz wniesioną przez rozmówców pełną informację na temat ówczesnej rzeczywistości politycznej w Europie, w tym na ziemiach polskich, a także ich sądów - postaw oceniających wobec przedmiotu audiencji i padających w niej wypowiedzi, jaką dawał

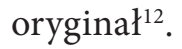

Informację przedmiotowo-pojęciową budowały sensy niesione/wytwarzane $\mathrm{w}$ wypowiedzeniach składających się na wypowiedzi-repliki audiencji, rozumiane jako jednostki dialogu (Bachtin 1986: 365-366). I niewątpliwie wierność sensom oryginału była dla Krasińskiego najważniejsza w hierarchii wartości, które należało zachować w tłumaczeniu (Koller 2009: 154). Sensy dyskursu mówionego Krasiński

12 Tłumaczenie Krasińskiego odpowiadało więc dwóm kryteriom ekwiwalencji przekładowej postulowanym przez teoretyka przekładoznawstwa Wernera Kollera: kryterium ekwiwalencji denotatywnej (denotative Äquivalenz) oraz tekstowo-normatywnej (textnormative Äquivalenz) (za: Lederer 1994: 64-65; Koller 2009: 146-159). 
przenosił do dyskursu II stopnia poprzez działania, jakich dokonują na tekście wyjściowym i docelowym osoby dwujęzyczne. Krasiński jest takim właśnie przypadkiem tłumacza, który jako bilingwista żył w dwóch językach, tj. był zdolny przechodzić z jednego języka na drugi, gdy taka zachodziła potrzeba komunikacyjna, oraz był zdolny podejmować w obu językach wszystkie rodzaje działań językowych kodowania nowych treści (Ligara 2015).

Współobecność dwóch języków w umyśle bilingwisty może wytwarzać relacje interpretacyjne między nimi. Georges Lüdi i Bernard Py uznają funkcję interpretacyjną za kluczowe pojęcie bilingwizmu; upatrują ją w tym, że każdy język ma moc kategoryzowania rzeczywistości - systemu językowego, dyskursów publicznych i prywatnych, kultury, wszystkich codziennych działań językowych - w sposób sobie właściwy. Proces, poprzez który u bilingwisty jeden język jest kategoryzowany przez drugi (język), jest właśnie interpretacją. Każdy z dwóch języków może zatem być u osoby dwujęzycznej tak narzędziem komunikacji, jak i metajęzykiem dla drugiego języka (Lüdi, Py 2003: 73-79). Operacje mentalne dokonujące się w umyśle bilingwisty między jego dwiema przestrzeniami językowymi J1 i J2, a taką jest tłumaczenie, są w istocie rzeczy operacjami metajęzykowymi w rozumieniu R. Jakobsona. U osoby dwujęzycznej jeden język interpretuje, tzn. kategoryzuje drugi, ponieważ u podstaw konkretnej sytuacji komunikacyjnej leży zawsze wybór kodu: bilingwista aktywuje jeden z dwóch (czy więcej) kodów swojego zasobu językowego, a dezaktywuje drugi, który jednakże pozostaje w jego umyśle obecny (Grosjean 2015: 56-69). I właśnie eksplicytne ślady działań metajęzykowych, których Krasiński dokonał w operacji przenoszenia dyskursu mówionego w J1 do przestrzeni J2, będą teraz przedmiotem opisu jako istotne dla procesu wyłaniania się tekstu tłumaczeń. Uobecniają bowiem materialnie ulotny oryginał, a także stawiają pytanie badawcze: dlaczego Krasiński tych akurat fragmentów oryginału „nie ukrył” za swoim drugim kodem, a przeciwnie, przetransponował je do dyskursu II stopnia, mimo że TW winien był pozostać całkowicie nieutrwalony?

\section{Metajęzykowe działania w translacji audiencji - efekty bilingwizmu tłumacza}

Językiem wymiany konwersacyjnej Napoleona III z Krasińskim był francuski, niemniej miały w niej miejsce przełączenia kodów (CS) na angielski, niemiecki oraz łacinę (zob. niżej 3.5.). Oryginalny dyskurs mówiony aktualizował zatem wielojęzyczność - tutaj użycie czterech języków - europejskich elit kulturalnych, intelektualnych, politycznych XIX w., ale najwyższy prestiż społeczny przypisywany był francuszczyźnie, językowi podstawowemu audiencji. Natomiast dyskurs II stopnia również odbija wielojęzyczność oryginału, ale zmienia w translacji tryb językowy obu dialogów z pierwotnego dominującego jednojęzycznego (francuskojęzycznego) na dwujęzyczny: został zatem zrealizowany jako typowa dla zachowania językowego 
bilingwistów mowa dwujęzyczna, w której językiem podstawowym - bo zarazem językiem tłumaczenia - jest polski (J2 Krasińskiego w pierwotnej sytuacji wypowiadania), a francuski (odpowiednio J1 tejże samej sytuacji) językiem elementów wstawionych do tekstu polskiego ${ }^{13}$. Elementy obcojęzyczne w wypowiedzi/tekście naruszały normę zwyczajową języka docelowego tłumaczeń nieprzychylną tzw. makaronizmom. Dodajmy, że tłumaczenia audiencji aktualizowały w ten sposób pięć języków: polski, francuski, angielski, niemiecki, łacinę.

Transfer francuskich elementów oryginału mówionego nie wynikał z niedostatecznej kompetencji Krasińskiego tłumacza. Odzwierciedla natomiast wybór, jakiego w danym działaniu komunikacyjnym dokonywał bilingwista. Wybierał mianowicie tę możliwość językową spośród mu dostępnych w repertuarze językowym, która $\mathrm{w}$ akcie tłumaczenia danej wypowiedzi-repliki wydawała mu się z pewnych względów relewantna. Zatem już sama zmiana kodu polegająca na umieszczaniu przez Krasińskiego elementów należących do J1, francuskiego, w tekście aktualizowanym w języku polskim, czyli bazowym mowy dwujęzycznej, jest $\mathrm{w}$ istocie działaniem metajęzykowym: język francuski, tj. wstawiony, zostaje $\mathrm{w}$ danym polskim kontekście zinterpretowany z punktu widzenia nadawcy - bilingwisty - jako relewantny. Podobnie rzecz się ma $\mathrm{z}$ wstawieniem do dyskursu II stopnia trzech pozostałych języków z ogólnej puli zasobów językowych Krasińskiego.

Efekty działań metajęzykowych przybierają $\mathrm{w}$ tłumaczeniu audiencji różną postać/formę, bardziej lub mniej widoczną na poziomie tekstu, tzn. odcinającą się od języka podstawowego lub nie: od przełączeń kodów, które funkcjonują jako fragmenty nieprzetłumaczone, poprzez interferencje indywidualne, po działania ustalenia wspólnych znaczeń w sytuacji różnicy między dyskursem I stopnia i dyskursem II stopnia, w tym „skok w metajęzyk” (termin Wernera Kollera (2009: 157-158), za Haraldem Weinrichem).

3.1. Jako bilingwista doskonały Krasiński przełączał kod polski (kod tłumaczenia) na kod francuski (kod oryginału), nie naruszając struktury ani reguł obu kodów. Reprodukcji zaś w języku francuskim dokonywał ze względu na komponent referencjalny, jaki CS wnosił do tłumaczonej wypowiedzi-repliki (Lüdi, Py 2003: 77-78). $\mathrm{Z}$ treściami referencjalnymi wstawionych CS mogły się łączyć dodatkowe konotacje $\mathrm{w}$ języku oryginału, równie ważne informacyjnie. $Z$ tej racji sensy danych wypowiedzi-replik z umiejscowionym w nich francuskim CS przystawały, w poczuciu językowym bilingwisty, bardziej adekwatnie do uniwersum referencji związanego z językiem, w którym powstał oryginalny dyskurs mówiony, niż odtworzone w tworzywie języka tłumaczenia.

13 Pojęcie mowy dwujęzycznej i związane z nim instrumentarium pojęciowo-badawcze omawiam w: Ligara 2014a, 2014b. 
Zatem do realnej rzeczywistości, w której przebiegały zdarzenia komunikacyjne, odnoszą się następujące francuskie CS:

(1) [Wielka księżna Stefania, ciotka Napoleona III] Wyszła, przyjęła go [synowca, Napoleona III], wróciła po mnie, wyprowadziła mnie i mówiąc [do Napoleona III o Zygmuncie Krasińskim]: „Il est sur des béquilles” (J1), przedstawiła mnie jemu. Potem weszła nazad do swej sypialni, zostawując mnie z nim sam na sam (Pierwsze 1857: 271, wyróżnienie -B.L. ${ }^{14}$ )

[= Jest o kulach ${ }^{15}$,

gdzie CS reprodukuje oryginalny cudzy głos trzeciej uczestniczki pierwotnej sytuacji, a przez to informuje też o tym, do jakiej wspólnoty językowej/komunikatywnej ona należała;

(2) [Napoleon III] Na to wszystko przystawał, potakując, ale powtarzając: „Tak jest, ale to niezmiernie trudne. Rządy europejskie tak mało mają samoistności i d'initiative" (J1) (Drugie 1858: 283)

[= inicjatywy, tłum. - B.L.],

konceptualizujące w języku francuskim prymarnie 'działanie jakiejś osoby, która jako pierwsza ma zaproponować, przedsięwziąć, zorganizować coś' (tłumaczenie i wyróżnienie - B.L.) ${ }^{16}$ - tu deficyt woli owego działania u rządów europejskich wobec inicjatywy (w J2) konceptualizującej prymarnie raczej wstępny „bodziec, impuls do działania; projekt, pomysł do realizacji, propozycję" (SJPSz I: 790, wyróżnienie - B.L.).

Do uniwersum referencji związanego z językiem audiencji należą również akty mowy dokonujące się w replikach - interakcjach rozmówców. Rzeczywiste, tzn. mające wartość prawdy bez językowego filtru drugiego języka, są w tłumaczeniu dwa akty mowy odtworzone słowami wypowiedzianymi przez Napoleona III. Jest to zachowaniowy akt powitania (i równocześnie przedstawienia się) skierowanego do Krasińskiego, w bardzo uprzejmej formule:

(3) Charmé de faire votre connaissance $\left(\mathrm{J}_{1}\right)$ - i kazał siedzieć na kanapie, sam usiadł na krześle szerokim (Pierwsze 1857: 271)

[= Miło mi, że mogę Pana poznaćc]

14 Wyróżnienia w cytatach z tekstów Z. Krasińskiego pochodzą ode mnie.

15 Tłumaczenia oryginałów: francuskich i dalej angielskiego oraz niemieckiego podaję za: Hertz 1999: 291-342, chyba że pochodzą ode mnie (w takim wypadku oznaczam to w nawiasie).

16 Zob. LNPR: hasło Initiative to „Action d' une personne qui est la première à proposer, entreprendre, organiser qqch". 
oraz pośredni akt silnego nalegania o zachowanie tajemnicy audiencji, wywieranego ze strony Napoleona III na Krasińskim:

(4a) I przydał tu: - Ce que je vous dis, vous en sentez, est fort confidentiel (J1) (ibid.: 273) [= Pojmuje Pan, że to, co Panu mówię, jest ściśle poufne],

powtórzony pod koniec audiencji, tym razem jako akt bezpośredni - przetłumaczony i równocześnie przeformułowany na wariantywną formę mowy zależnej:

(4b) [Napoleon III] Po trzech kwadransach lub godzinie rozmowy sam na sam, podczas której sam prawie ciągle przemawiał, i to nadzwyczaj gładko, płynnie, uprzejmie, łagodnie, niewymuszenie, tak jak człowiek, co mówi jak najszczerzej, a liczy na to, że słuchacz nie powtórzy słów słyszanych (J2), wstał, podał mi rękę [...] i rzekł: Miło mi, żem poznał pana hrabiego (ibid.: 275).

U podstaw operacji przeniesienia do dyskursu II stopnia sprawczych aktów (3) i (4a) w języku audiencji, a nie przetłumaczenia ich na J2 (jak w (4b)), leżał ich instytucjonalny wymiar $\mathrm{z}$ góry określający charakter relacji interpersonalnych między uczestnikami posłuchań. A ważnym ich składnikiem-wyrazicielem był sam język, tu francuski, stąd oryginalne CS o treści pragmatycznej w tekście tłumaczenia (Ligara 2014b: 166).

Krasiński wybrał też francuskie CS, by przenieść z dyskursu I stopnia dwie rzeczywiste wypowiedzi Napoleona III: stanowiły one odniesienie się - komentarze Napoleona III do replik jego rozmówcy i, co istotne, ich nieprzetłumaczona postać wyrażała bezpośrednio punkt widzenia Napoleona III, tak ważny dla świadka-uczestnika audiencji:

(5) O stan Rosji zaczął się wypytywać - [Z. Krasiński] Szlachta rosyjska postanowiła - rzekłem - że nie odstąpi prawa swego do jednej piędzi ziemi, choć da wolność chłopom; stąd powstanie między nią a rządem starcie się. Przed kilku dniami w Vichy generał Roztopcow rzekł, mówiąc o właścicielach rosyjskich: „Tego roku im jeszcze nic nie będzie, ale na przyszły niech się strzegą". - [Napoleon III] C'est une grosse affaire (J1) (Drugie 1858: 281-282) [= To gruba sprawa],

gdzie CS wyraża opinię Napoleona III na temat przedstawionej mu przez rozmówcę sytuacji w Rosji, a oryginał mówiony wzmacnia jeszcze ocenę tej sytuacji konotując treść ewaluatywną 'poważna' w odniesieniu do 'sprawa [= affaire] ${ }^{17}$;

17 Zob. LNPR: hasło przymiotnik gros, grosse w znaczeniu 'grave' [= poważna]. 
(6) [Z. Krasiński] Bo w istocie i we Francji też wojna tylko może rewolucji społecznej przeszkodzić. - [Napoleon III] Tak - ale (J2) une guerre juste (J1) (ibid.: 282)

[= wojna sprawiedliwa],

gdzie CS jest wypowiedzią Napoleona III polemizującą z opinią Krasińskiego co do przyszłej wojny, zatem rzeczywista forma tej polemiki ma siłę argumentu z autorytetu, jakim był ówcześnie cesarz Francuzów.

3.2. Jeszcze inne działanie metajęzykowe ma miejsce w śladach podwójnego myślenia językowego u Krasińskiego bilingwisty, odbitego w dyskursie II stopnia w ten sposób, że umieszczał on polskie odpowiedniki tłumaczeniowe obok oryginałów francuskich (segmentów w J1). Było to działanie polegające na poszukiwaniu ekwiwalencji znaczenia w sytuacji różnicy między jednostkami kodu tłumaczenia i kodu wyjściowego, jak w poniższych segmentach $(7)$ i (8) ${ }^{18}$ :

(7) [Napoleon III] W polityce mówi się tylko o tym, co jest urzeczywistnialnym w danej chwili; w obecnej zaś dwa tylko przypuszczenia mamy przed sobą: pierwsze, wojny olbrzymiej, przewracajacej wszystkie stosunki i układy europejskie (J2) (grands bouleversements (J1)), a w takiej wojnie kto odgadnąć potrafi, jak się ułożą przymierza pomiędzy państwami europejskimi? Zatem trudno co bądź o tej przypuszczalnej formie przyszłości powiedzieć (Pierwsze 1857: 272),

gdzie Krasiński uzyskał ekwiwalencję znaczenia między segmentem w J1 i jego tłumaczeniem na J2 w ten sposób, że odwzorował słowo bouleversements dsł. 'wstrząsy', 'przewroty', eksplikując na powierzchni tekstu jego komponenty znaczeniowe jako „wojna” + „przewracająca” oraz dodając interwencję metajęzykową w postaci grupy „wszystkie stosunki i układy europejskie”. Przenosi ona do warstwy eksplicytnej tłumaczenia ówczesne implicite dotyczące sytuacji polityczno-społecznej, zaś kwantyfikator ogólny „wszystkie” nadaje „stosunkom i układom europejskim” budzące lęk znaczenie bezwyjątkowości, jest więc pewną nadwyżką semantyczną;

(8) [Napoleon III] Drugie, na co zdaje się prawdopodobnie zanosić, że trwać będzie stan pokoju i dyplomatycznych układów, rozstrzygających o świecie. Trzymajmy się więc owego drugiego przypuszczenia (hypothèse). W nim zdaje mi się, że jedynym sposobem pomożenia wam byłoby [...] (ibid.: 273, rozstrzelenie w oryginale),

18 Roman Jakobson (2009: 44) uznaje ekwiwalencję w sytuacji różnicy za „podstawowy problem języka i główny przedmiot zainteresowania językoznawstwa”. 
w którym ekwiwalent tłumaczeniowy „przypuszczenie” doprecyzował Krasiński realnie wypowiedzianą przez Napoleona III hypothèse, uszczegółowiającą, iż mówiącemu chodziło o 'przypuszczenie dotyczące możliwości jakiegoś wydarzenia (tłumaczenie i wyróżnienie - B.L.)'19.

Natomiast gdy translacja obejmowała cały komunikat, tłumacz dążył do jego adekwatnej interpretacji, wspierając się tekstem wyjściowym:

(9) [Napoleon III] A już z początku był wyrzekł frazes: - Wojna teraz nie jest prawdopodobna z Moskwą, my się raczej umizgamy do siebie (nous sommes plutôt en coquetterie avec la Russie) (ibid.: 274).

Tłumaczenie komunikatu (wyróżnionego w powyższym cytacie kursywą) opatrzył Krasiński rzeczywistą wypowiedzią Napoleona III, który formułuje w niej swoją ocenę relacji Francji z Rosją, dla sprawy polskiej - kluczową (Ligara 2014b: 166). Oryginalny komunikat Napoleona III pełni zatem ważną funkcję poznawczą: stanowi dla TD kontekst kompensujący ewentualną utratę części informacji w translacji, tu nie dość dobitnie odwzorowanej oceny, o której wyżej mowa.

3.3. Krasiński tłumacz czerpał ze swojego podwójnego zasobu językowego również na poziomie leksykalnym, tworząc na potrzeby translacji interferencje między znakami języka oryginału i języka tłumaczenia, a więc jednostki językowe nienależące całkowicie do systemu leksykalnego ani J1, ani J2, a przez to nieakceptowane przez normę ${ }^{20}$ :

- zmonarszeć < fr. monarch/iser z dodaniem pol. morfemów: tematu czasu przeszłego -e- oraz bezokolicznika -ć, ze znaczeniem fr. przenośnym 'pokazać się jako monarcha' ${ }^{\prime 21}$ :

(10) Postać szlachetna, raczej arystokratyczna, raczej wielkiego bardzo pana niż monarchy, lecz znać było, że sam chciał tak wyglądać w tej chwili i że co chwila mógłby zmonarszeć na powrót (Pierwsze 1857: 271);

- kalka wyrazowa *u/rzeczywistni/alne, u/rzeczywistni/alnym na wzór modelu fr. réalis/able 'wykonalny, dający się zrealizować ${ }^{22}$, z substytucją polskich morfemów leksykalnego i słowotwórczych (u-, -alne), w znaczeniu jak wyżej:

(11) [Napoleon III] W polityce mówi się tylko o tym, co jest urzeczywistnialnym w danej chwili (ibid.: 272);

19 Zob. LNPR: hasło Hypothèse „conjecture concernant [...] la possibilité d’ un événement”.

20 Interferencje wyekscerpowane z Posłuchań zostały sfalsyfikowane w SL, SWil, SW, SJPD.

21 Zob. TLFI: hasło Monarchiser "se montrer favorable à la monarchie”.

22 Zob. TLFI: hasło réalisable "Qui peut être accompli, exécuté”. 
- kreacja językowa ${ }^{*} z$ darzenność, zdarzenności inspirowana fr. słowem (przymiotnikiem) événement/iel 'tworzący, konstytuujący zdarzenie, zdarzenia' ${ }^{23}<\mathrm{fr}$. l'événement 'zdarzenie' - na tym modelu derywowana $\mathrm{w}$ J2 od podstawy $z$ darzenie $\rightarrow$ (przym.) ${ }^{\star} z$ darzenny $\rightarrow{ }^{*}$ zdarzenność jako własny twór językowy Krasińskiego 'układ zdarzeń':

(12) [Z. Krasiński] [...] pamiętaj, najjaśniejszy panie, o narodzie, który jeden ze słowiańskich jest w pełni katolickim, zachodnim, jest koniecznym Francji sprzymierzeńcem i do tego najwierniejszym był dynastii twojej. [...] Pamiętaj, najjaśniejszy panie, nie dać go zatracić. Co możesz, w każdej zdarzenności czyń (ibid.: 274).

Interferencje dokonane pod wpływem J1 podsunął Krasińskiemu kontekst sytuacyjny (jak (10)), słowa cudze Napoleona III (jak (11)) i słowa własne (jak (12)) dyskursu mówionego; w akcie tłumaczenia "na gorąco" ujawniają one eksplicytnie, bo na poziomie słów, działania wywierane przez jeden język (tu francuski) na drugi język (tu polski) bilingwisty, nie automatycznie jednak, ale poprzez interwencję metajęzykową podmiotu mówiącego (Lüdi, Py 2003: 78).

3.4. Działania negocjowania znaczeń wspólnych między jednostkami leksykalnymi należącymi do dwóch przestrzeni językowych $\mathrm{J}_{1}$ i J2 $\mathrm{w}$ sytuacji różnicy na planie pojęciowym były dokonywane przez Krasińskiego w autotłumaczeniu. Brak ekwiwalencji semantycznej wynikał z odmiennego implicite kulturowego w J1 i w J2 którego Krasiński jako bilingwista był świadom - mającego swój wyraz na planie językowym w odmiennych konotacjach słów języka oryginału i języka tłumaczenia ${ }^{24}$. Ustalanie wspólnych znaczeń stało u podstaw operacji określenia nazwą, a więc i skategoryzowania w dyskursie I i II stopnia dwóch podmiotów społecznych i tym samym politycznych: $\mathrm{z}$ jednej strony nazwanie osób zaliczanych do klasy ludowej, $\mathrm{z}$ drugiej nazwanie wspólnoty narodowej. Te dwa byty osadzone są w języku i bez niego nie istnieją.

Można domniemywać, że osoby należące do klasy ludowej Krasiński nazywał $\mathrm{w}$ dyskursie I stopnia ${ }^{*}(l e)$ paysan, zgodnie z systemem leksykalnym $\mathrm{J}^{25}$; osoby zaś należące do tejże klasy w Rosji opatrywał mianem chłop i, co ciekawe, nazwą $m u$ $\dot{z} y k$, nieznaną Napoleonowi III, czego śladem w dyskursie II stopnia jest poniższy fragment:

23 LNPR : hasło événementiel, ielle „Qui constitue un événement”.

24 Problematykę konotacji w przekładzie omawia J.-R. Ladmiral (1994: 115-203).

25 Zob. TLFI: hasło paysan (w użyciu rzeczownikowym) „Personne de la campagne qui vit de la culture du sol et de lélevage des animaux" [= 'osoba ze wsi, która żyje z uprawy ziemi i hodowli zwierząt', tłumaczenie - B.L.]. 
(13) [Z. Krasiński] Szlachta rosyjska postanowiła - rzekłem - że nie odstąpi prawa swego do jednej piędzi ziemi, choć da wolność chłopom; [...] W istocie, najjaśniejszy panie, i tak to sprawa coraz groźniejsza, że nie dziwiłbym się wcale, gdyby rząd rosyjski dla zyskania czasu, dla odwleczenia rzezi społecznej, użył jedynej zasady, to jest wojny z Niemcem, bo to jedno by jeszcze mogło na czas uwagę mużyków ściągnąć ku czemu innemu. - [Napoleon III] Zapytał się, co to $\mathbf{m u \mathbf { z }} \mathbf{y k}$. (Drugie 1858: 282, rozstrzelenie autora) ${ }^{26}$.

Wyraz muży jest odnotowany w SJAM (t. IV) u Adama Mickiewicza ze znaczeniem 'chłop rosyjski' oraz w SW (t. II) z tymi samymi poświadczeniami. Krasiński dokonał transferu odnośnej nazwy / odnośnego pojęcia ze swojego doświadczenia w J2 ze względu na implicite i konotację kulturową, a nawet ideologiczną tego słowa 'człowiek żyjący w poddaństwie pańszczyźnianym, bliskim niewolnictwu' (Ladmiral 1994: 200). Jego obcość wniósł Krasiński do dyskursu mówionego (w J1), uzyskując określony efekt poznawczy: kontrast niemal „ontologiczny” między fr. *paysan z konotacją 'człowiek wolny' i rosyjskim mużykiem 'człowiekiem niewolnym, żyjącym prawie w niewolnictwie'.

Gdy idzie o nazwę wspólnoty narodowej w J1 - le peuple - Krasiński, nosiciel dwóch języków, skojarzył ją z pol. nazwą lud w znaczeniu 3. 'niższe warstwy społeczeństwa, pospólstwo, gmin’ (SW II: 772) ${ }^{27}$. Mając w swoim zasobie językowym dwa wyrazy o odmiennym implicite kulturowym, dokonał transferu konotacji ideologicznej nacechowanej pejoratywnie polskiego lud (wynikającej ze znaczenia jw.) do J1, tak interpretując w dyskursie I stopnia słowo peuple w przywołanym "głosie” Napoleona I:

(14) [Z. Krasiński] Dalej ciągnąłem: - Najgłówniejszą w świecie niesprawiedliwością jest uciemiężenie narodowości. Wojnę wypowiedzieć o tę świętą zasadę. Stryj twój, najjaśniejszy panie, wyrzekł: [głos Napoleona I] „Pierwsze lepsze książątko, co dobędzie miecza w sprawie narodowości europejskich, będzie panem świata”. [komentarz metajęzykowy - „skok w metajęzyk”] Wyraził się w istocie peuples, a nie nations - lecz pewno nie myślał o motłochu, jedno

26 Natomiast osoby należące do klasy ludowej żyjące na ziemiach polskich Krasiński nazywa/kategoryzuje jako włościanie: „Ja [...] nadmienię, że wojsko francuskie wylądowując do Litwy, trafiało na drugą Francję, i że w miejscu twierdzy mogło obozy okopne stawiać i w sześć miesięcy mieć całą przestrzeń Polski zorganizowaną orężnie, gdyż wiadomo, że włościanin nasz w sześć tygodni czasu doskonałym staje się żołnierzem. On. Co do włościanina polskiego, wiem, że tak jest [...]" (Pierwsze 1857: 272) oraz „W danym razie, gdyby wojsko jakie ukazało się za Polską na polskiej ziemi, wszyscy by włościanie za szlachtą poszli" (Drugie 1858: 284).

W SW (t. VII) włościanin to 'gospodarz wiejski' bez konotacji '(chłop) poddany'.

27 Dwa inne znaczenia wyrazu lud odnotowane w SW to 1. 'ludzie', 2. 'naród, szczególnie nieucywilizowany'. Zob. także: Ligara 2014b: 167. 
o narodach całych. - [Napoleon III] Nie ma żadnej wątpliwości - rzekł mi na to - że taką jego myśl była (Drugie 1858: 282)

[peuples $=$ ludy], [nations $=$ narody].

Konfliktowe sensy fr. peuple(s) i przypisanego mu przez Krasińskiego polskiego znaczenia motłoch 'gawiedź, tłuszcza, zgraja, pospólstwo' (SW II: 1050) wymagały uzgodnienia wspólnego znaczenia na płaszczyźnie semantyki międzyjęzykowej: w komentarzu metajęzykowym Krasiński przypisał francuskiemu peuple w ustach Napoleona I znaczenie nation, pol. naró ${ }^{28}$. Komentarz ten odzwierciedla negocjowanie wspólnych znaczeń między nieekwiwalentnymi konotacjami w obu językach.

3.5. Wielojęzyczność, jaka cechowała dialogi Krasińskiego z cesarzem Napoleonem III, została w tłumaczeniu zachowana. Tym samym translacja oddaje ich europejski wymiar ${ }^{29}$. Krasiński przeniósł do dyskursu II stopnia innojęzyczne segmenty, jakie zostały wypowiedziane w TW, w postaci przełączeń kodów o różnym obciążeniu funkcjonalnym. Co ciekawe, innojęzyczne CS dają się zaobserwować tylko w replikach Krasińskiego (a więc w autotłumaczeniu); przestawiał się on jednak z trybu jednojęzycznego francuskiego na inne języki tylko dlatego, że pozostawał w interakcji z drugą taką samą osobą, o czym informuje:

Nie był słyszał [Napoleon III] o tym [słowach Marii Teresy na temat jej podpisu na akcie rozbioru Polski]; ogromnie te słowa go zastanowiły. Doskonale umie po niemiecku i zrozumiał je zaraz (Drugie 1858: 287).

Przeskok na język angielski wewnątrz wypowiedzenia pojedynczego miał retoryczną funkcję wzmocnienia treści afektywnej przekazu mającej wpłynąć na rozmówcę; uzyskał je Krasiński poprzez skontrastowanie - grę językową z wcześniejszymi słowami swojego rozmówcy jeszcze jako prezydenta Republiki Francuskiej: (fr., język ojczysty Napoleona III) L'empire c'est la paix vs. (ang.) an imperial peace:

28 Znaczenie słowa peuple bliskie nation odnotowują jako pierwsze słowniki francuskie, np. TLFI, LNPR. Odnotowują również znaczenie bliskie pol. pospólstwu: TLFI: „L' ensemble des personnes qui n’appartiennent pas aux classes dominantes socialement, économiquement et culturellement de la société" [= 'ogół osób, które nie należą do klas dominujących ekonomicznie i kulturowo społeczeństwa', tłum. - B.L.]. Zatem Krasiński, wybierając znaczenie pierwsze, usunął ambiwalencję znaczeniową słowa peuple. Analizę leksykalno-semantyczną słów peuple, nation przeprowadziła Sylvianne Rémi-Giraud (1996), zaś pol. naród - Jadwiga Puzynina (1998) oraz Monika Bednarczuk (2009).

29 Zagadnienie analizy tekstu wielojęzycznego oraz gramatyki wielojęzyczności omawia Anna Mazur (2019: 382-386). 
(15) [Z. Krasiński] Wasza cesarska mość wyrzekłeś: „Cesarstwo pokojem”30 i prawda - lecz niechże to będzie pokój godny tego nazwiska, stały, długi, wieczny, jeśli co na ziemi tego przydomku brzemię nieść zdoła; niech to będzie, jakby Anglik powiedział, an imperial peace, a do takiej [sic!] imperial peace jakże trafić, jeśli nie wojną, ostatnią może - ależ wojna zawsze, bo czyż dzisiejszy pokój ma jakie bądź w sobie rękojmie bytu? Czyż co chwila się nie rwie i rwać się nie będzie? (ibid.: 282-283, uwaga - B.L.)

[= cesarski pokój];

w wypowiedzeniu zaznacza się wpływ języka audiencji (fr.) na ang. CS na poziomie systemowym (morfologicznym) w postaci przypisania rzeczownikowi peace rodzaju żeńskiego pod wpływem fr. la paix.

Niemieckie CS w dyskursie II stopnia reprodukują bezpośrednio za oryginałem (czyli tak, jak w dyskursie mówionym) wypowiedzi dwóch polityków; mają one charakter opiniotwórczy i przez to są szczególnie ważne dla tematu audiencji:

- wypowiedź cesarza austriackiego Franciszka Józefa I:

(16) [...] i zapytał się [Napoleon III] mnie, czy znam cesarza austriackiego. [Z. Krasiński] Osobiście nie, najjaśniejszy panie, ale dużo o nim słyszałem. Generał Haynau opowiadał, że gdy go wyprawiał na Węgry, rzekł mu: „Machen Sie, was Sie wollen, bloss keine Gnade”, i tym się zastawiał Haynau przed ścigającym go zarzutem okrucieństwa (ibid.: 286).

[= Proszę robić wszystko, co Pan zechce, byle nie okazywać łaski],

- wypowiedź cesarzowej Marii Teresy:

(17) [Z. Krasiński] Rozmowa znów wróciła do Polski. Wspomniałem o pewnych frazesach austriackich niby to żałujących rozbioru [Polski - B.L.], o Marii Teresie, i przytoczyłem słowa, które własną ręką przydała do podpisu swego na akcie poddziału: „Ich tue es, weil so kluge und erfahrene Männern(s) es wollen - aber wenn schon lang tot ich bin, man wird erfahren, was aus dieser Verletzung von allem, was rechtes und heiliges ist, hervorgehen wird". Nie był słyszał o tym; ogromnie te słowa go zastanowiły (ibid.: 286-287) [= Robię to, ponieważ tak chcą mądrzy i doświadczeni ludzie - ale kiedy ja już dawno nie będę żyła, ludzie dowiedzą się, co z tego pogwałcenia wszystkiego, co jest sprawiedliwe i święte, pokaże się; tłumaczenie filologiczne - B.L.].

30 Oryginalne wcześniejsze słowa to: L'empire c'est la paix. Krasiński tłumaczy słowa księcia Ludwika Napoleona, późniejszego Napoleona III, które ten wypowiedział sześć lat wcześniej na bankiecie w Bordeaux 9 września 1852 r. (zob. Hertz 1999: 340). 
Niemieckie przytoczenia pełnią w tłumaczeniu funkcję dyskursywną polegającą na wprowadzeniu polifonii cudzych głosów, a zachowanie ich w oryginalnej postaci było w zamyśle Krasińskiego gwarantem ich autentyczności.

Łacińskie CS to maksyma skierowana do Napoleona III; Krasiński użył jej jako środka retorycznego wnoszącego gotowe treści dla celu argumentacyjnego:

(18) [Z. Krasiński] - Wszystko trudnym, prawda - ale tylko trudnymi czynami można świat zbawić od społecznego zamętu, najstraszniejszego, jaki był w dziejach, a grożącego zniszczeniem tej epoce - per angusta ad augusta, najjaśniejszy panie! (ibid.: 283)

[= ciasnymi drogami do wzniosłych wyników, tłumaczenie - B.L.].

Jak każda maksyma, posłużyła ona Krasińskiemu jako argument, z którym się nie dyskutuje, gdyż odwołuje się do wartości, podzielanych - w opinii nadawcy - przez jego rozmówcę. Ale jest jedynie utartą formułą, a nie inwencją językową $\mathrm{w}$ drugim języku, jak to ma miejsce $\mathrm{w}$ angielskim CS (15).

\section{Wnioski. Bilingwizm - narzędzie tłumacza}

Pierwsze postuchanie i Drugie postuchanie, będące tłumaczeniem dwu audiencji gatunku, co należałoby podkreślić, mówionego - udzielonych Zygmuntowi Krasińskiemu przez cesarza Napoleona III, otwierają dwa pola obserwacji. Pierwsze pole, translatologiczne, to wyłanianie się z dyskursu mówionego w J1 tekstu zapisanego w J2, które się uwidacznia jako proces w akcie tłumaczenia. Obejmuje ono akt zapamiętania szeregu replik powiedzianych $\mathrm{w} \mathrm{J}_{1}$, francuskim (i w trzech innych kodach), $\mathrm{w}$ obu zdarzeniach komunikacyjnych, a następnie akt ich przełożenia-utrwalenia $\mathrm{w}$ języku polskim $\left(\mathrm{J}_{2}\right)$, przez uczestnika audiencji i zarazem tłumacza, w postaci tekstu semantycznie równoważnego dialogom wyjściowym. Mógł tego dokonać tylko bilingwista doskonały, jakim był Krasiński, dzięki swojej wybitnej kompetencji dwujęzycznej.

Działanie translatorskie Krasińskiego było dwojakie: tłumaczenie, z jednej strony, wypowiedzi Napoleona III, i wtedy było to działanie pośredniczące przenoszenia wypowiedzi cudzych z przestrzeni języka francuskiego - przestrzeni wiedzy i opinii francuskiej (i innych mocarstw) w połowie XIX w. - do przestrzeni języka polskiego, z drugiej zaś autotłumaczenie wypowiedzi własnych. W obu działaniach Krasiński tłumacz przyjął postawę zaangażowania co do dokładności, a więc wierności tłumaczonego przekazu względem oryginału.

Akt zapamiętywania zdarzenia komunikacyjnego, żeby je bezpośrednio przetłumaczyć w zapisie, leżał u postaw szeregu działań metajęzykowych Krasińskiego, który dokonywał translacji na $\mathbf{2} 2 \mathrm{w}$ trybie dwujęzycznym, tzn. nie dezaktywując 
całkowicie swojego J1, w którym audiencje przebiegały. Ich ślady w Posłuchaniach to: 1. przełączanie kodów, kiedy Krasiński przestawiał swoją translację na język oryginału (CS), 2. zapisywane podwójne myślenie językowe, 3. włączanie jednego systemu językowego do drugiego, jak interferencje, 4. negocjowanie wspólnych znaczeń w sytuacji różnicy między jednostkami językowymi dyskursu I stopnia i dyskursu II stopnia, a w jego ramach dwukierunkowy przepływ sensów/pojęć z jednej przestrzeni językowej do drugiej u bilingwisty ${ }^{31}$. Zaobserwowane u Krasińskiego działania językowe wpisują się w model hermeneutycznego aktu przekładu G. Steinera (por. punkt 1): etap agresji, tzn. usuwanie w cień oryginału przez przekład, odzwierciedlają działania 2. oraz 4., natomiast etap wchłonięcia, tzn. inkorporację poprzez import do tłumaczenia znaczenia i formy oryginału, odzwierciedlają działania 1. i 3. (Steiner 2018: 21, 372-378).

Znacząca obecność śladów oryginału mówionego w tłumaczeniu audiencji sprawia, iż jest ono w istocie mową dwujęzyczną (a nawet wielojęzyczną). Ślady te uzasadnia funkcjonalnie cel tłumaczenia, a była nim asercja prawdy przeżytego przez Krasińskiego w J1 doświadczenia. I są one wypadkową napięcia między werbalnym kształtem dwóch zdarzeń komunikacyjnych wytworzonym po francusku (a także z włączeniem elementów: angielskiego, niemieckich i łaciny) a werbalnym kształtem zapisu tłumaczącego. Natomiast jako gatunek tłumaczenie Posłuchań reprezentuje mediację językową, w której akt translacji jest w trakcie dokonywania się poprzez zapis, a sam tekst tłumaczony dopiero się wyłania, ponieważ tkwi jeszcze w dyskursie I stopnia, łącząc w ten sposób obie przestrzenie językowe. W mediacji językowej, będącej w istocie tłumaczeniem in statu nascendi, język oryginału staje się materialnie „częścią wyrażanych myśli”32 nadawców.

Drugie pole obserwacji to sam fakt zapisu obu zdarzeń komunikacyjnych jako dyskursu tłumaczącego. Uzmysławia on tłumaczenie jako szczególny typ komunikacji Krasińskiego, twórcy dwujęzycznego, z przyszłą polską wspólnotą narodową. Oto dzięki niemu Polacy otrzymali dostęp do realnych dwóch dialogów toczonych w sprawie polskiej w XIX w. we Francji - zapis tłumaczący odtworzył niemalże bliską czasowo sytuację wypowiadania, w której powstał dyskurs I stopnia. Krasiński podjął wysiłek zapisu tłumaczącego obu audiencji, gdyż miał świadomość ich wagi dla Polaków i płynącej stąd swojej odpowiedzialności za ich utrwalenie i prawdziwość ich translacji. Bilingwizm jawi się zatem jako narzędzie Krasińskiego tłumacza.

Warto nadto zauważyć, że utrwalając Postuchania w zapisie tłumaczącym wbrew obowiązkowi zachowania poufności, Krasiński wobec swojego rozmówcy Napoleo-

31 Pojęcie dwukierunkowego przepływu znaczenia wprowadził George Steiner (2018: 378).

32 Ten aspekt lingwistyki przekładu w ujęciu antropologicznym podkreśla Piotr Chruszczewski, pisząc, że język jest nie tylko „wysublimowanym narzędziem używanym w komunikacji do precyzyjnego wyrażania myśli”, ale także „składnikiem wyrażanych myśli” - „[...] jest on elementem rzeczywistości” i „może wydatnie przyczyniać się do różnych zmian rzeczywistości, w której funkcjonuje" (Chruszczewski 2018: 78, wyróżnienie - B.L.). 
na III w gruncie rzeczy jej nie złamał. Nie tylko dlatego, że Posłuchania pozostawały jednoegzemplarzowe i niedostępne odpowiednio przez 55 i 54 lata, bo do ich wydania w 1912 r., ale i dlatego, że tłumaczenie audiencji, poszerzając krąg potencjalnych odbiorców o odbiorcę polskiego, wykluczało równocześnie odbiorcę francuskiego. Polszczyzna była bowiem dla elit francuskich w XIX w. językiem nieznanym, użyta zatem w translacji pozostawała językiem „tajemnym” wobec dominujących ówcześnie innych języków. Wskazuje to pośrednio na status języka polskiego w Europie w XIX w.

\section{Źródła}

Pierwsze 1857: Z. Krasiński, Pierwsze postuchanie u Napoleona III, [w:] idem, Pisma filozoficzne i polityczne, wydał i notami opatrzył P. Hertz, Warszawa 1999, s. 271-275.

Drugie 1858: Z. Krasiński, Drugie postuchanie u Napoleona III, [w:] idem, Pisma filozoficzne i polityczne, wydał i notami opatrzył P. Hertz, Warszawa 1999, s. 281-287.

\section{Literatura}

Adam J.-M., 1999, Linguistique textuelle. Des genres de discours aux textes, Paris.

BACHтin M., 1986, Estetyka twórczości słownej, przeł. D. Ulicka, Warszawa.

Bartmiński J., NiebrzegGowska-Bartmińska S., 2009, Tekstologia, Warszawa.

Baylon Ch., Mignot X., 2002, Initiation à la Sémantique du langage, Paris.

BeDnarCzuk M., 2009, Rozumienie narodu i jego profilowanie we współczesnym języku polskim, „Etnolingwistyka. Problemy Języka i Kultury” 21, s. 85-101.

Charaudeau P., Maingueneau D., 2002, Dictionnaire dianalyse du discours, Paris.

Chruszczewski P., 2018, Przekładoznawstwo jako domena językoznawstwa antropologicznego, [w:] A.R. Knapik, P.P. Chruszczewski (red.), Między tekstem a kulturą. Z zagadnień przekładoznawstwa, San Diego, s. 77-94.

DąmвSка-Proкор U., 2010, Nowa encyklopedia przekładoznawstwa, Kielce.

Derrida J., 1996, Le monolinguisme de lautre ou la prothèse dorigine, Paris.

Grosjean F., 2015, Parler plusieurs langues. Le monde des bilingues, Paris.

Hertz P., 1999, Noty, [w:] Z. Krasiński, Pisma filozoficzne i polityczne, wydał i notami opatrzył P. Hertz, Warszawa, s. 291-342.

JАковSON R., 1989, Metajęzyk jako problem językoznawczy, [w:] idem, W poszukiwaniu istoty jezzyka, red. M.R. Mayenowa, przeł. M.R. Mayenowa, t. I, Warszawa 1989, s. 382-388.

JaKOBson R., 2009 [1959], O jezzkoznawczych aspektach przekładu, przeł. L. Pszczołowska, [w:] P. Bukowski, M. Heydel (red.), Współczesne teorie przekładu. Antologia, Kraków, s. $43-49$.

Koller W., 2009 [1988], Przekład literacki z perspektywy językoznawstwa. Czynniki warunkujace przekład na przykładzie tekstu Henryka Ibsena, przeł. P. Zarychta, [w:] P. Bukowski, M. Heydel (red.), Współczesne teorie przekładu. Antologia, Kraków, s. 145-172.

Ladmiral J.-R., 1994, Traduire: théorèmes pour la traduction [wyd. fotomechaniczne: Mesnil-sur-l'Estrée 2002]. 
Lederer M., 1994, La traduction aujourd'hui Le modèle interprétatif, Paris.

Ligara B., 2014a, Bilingwizm w tekście zapisany. Część I. Status lingwistyczny. Paradygmaty badawcze, „LingVaria” nr 1 (17), s. 149-167, https://doi.org.10.12797/LV.09.2014.17.10.

Ligara B., 2014b, Bilingwizm w tekście zapisany. Część II. Wykładniki transkodowe. Gatun$k i$, „LingVaria” nr 2 (18), s. 139-174, https://doi.org.10.12797/LV.09.2014.18.11.

Ligara B., 2015, Une vie dans deux langues, le bilinguisme polonais-français de Zygmunt Krasiński à la lumière de son cuvre épistolaire et littéraire, „Revue des Études Slaves” LXXXVI, nr 4, s. 427-445.

Ligara B., 2018, Dyskurs cywilizacyjny Zygmunta Krasińskiego w przestrzeni międzykulturowej, „LingVaria” nr 2 (26), s. 259-274.

LNPR: J. Rey-Debove, A. Rey, S. Chantreau, M.-H. Drivaud, Le nouveau Petit Robert. Dictionnaire alphabétique et analogique de la langue française, Paris 2007.

LüDi G., Py B., 2003, Etre bilingue, wyd. 3, Bern - Berlin - Bruxelles - Frankfurt am Main - New York - Oxford - Wien.

Maurois A., 1947, Histoire de la France, t. 2, imprimé en Belgique: Club du Livre Sélectionné.

Mayenowa M.R., 1979, Poetyka teoretyczna. Zagadnienia języka, wyd. 2 popr. i uzup., Wrocław - Warszawa - Kraków - Gdańsk.

Mazur A., 2019, Wielojęzyczność indywidualna jako problem badawczy lingwistyki. Przypadek Bronisława Malinowskiego, „LingVaria” nr 1 (27), s. 377-388, https://doi.org/10.12797/ LV.14.2019.27.26.

PuZynina J., 1998, Struktura semantyczna narodu a profilowanie, [w:] J. Bartmiński, R. Tokarski (red.), Profilowanie w języku $i$ w tekście, „Czerwona Seria” Instytutu Filologii Polskiej UMCS 9, Lublin, s. 259-276.

RAstier F., 1996, La sémantique des textes; concepts et applications, „Hermes” 16, s. 15-37, [on-line:] http://www.revue-texto.net/Inedits/Rastier/Rastier_Concepts.html.

RÉmi-Giraud S., 1996, Le micro-champ lexical français peuple, nation, État, pays, patrie, [w:] S. Rémi-Giraud, P. Rétat (red.), Les mots de la nation, Lyon, s. 19-39.

Ricoeur P., 2003, Mowa i pismo, przeł. K. Rosner, [w:] G. Godlewski (red.), Antropologia słowa. Zagadnienia i wybór tekstów, Warszawa, s. 423-429.

SJAM: K. Górski, S. Hrabec (red.), Słownik języka Adama Mickiewicza, t. I-XI, Wrocław 1962-1983.

SJPD: W. Doroszewski (red.), Słownik języka polskiego, t. I-XI, Warszawa 1958-1961.

SJPSz: M. Szymczak (red.), Słownik języka polskiego, t. I-III, Warszawa 1978-1981.

SL: S.B. Linde, Słownik języka polskiego, t. I-VI, wyd. 2 popr. i zm., Lwów 1854-186o.

Steiner G., 2018, Po wieży Babel. Aspekty języka i przekładu, przeł. O. i W. Kubińscy, Warszawa.

SW: J. Karłowicz, A.A. Kryński, W. Niedźwiedzki (red.), Słownik języka polskiego, t. I-VIII, Warszawa 1900-1927.

SWil: A. Zdanowicz, M. Bohusz Szyszko, J. Filipowicz, W. Tomaszewicz, F. Czepieliński, W. Korotyński, z udziałem B. Trentowskiego, Słownik języka polskiego, t. I-II, Wilno 1861.

ŚwiĘCH J., 2015, Tłumacz i jego działania na tekście, [w:] S. Niebrzegowska-Bartmińska, M. Nowosad-Bakalarczyk, T. Piekot (red.), Działania na tekście. Przekład - redagowanie - ilustrowanie, „Czerwona Seria” Instytutu Filologii Polskiej UMCS 35, Lublin, S. 9-43.

TLFI: Trésor de la Langue Française informatisé, [on-line:] http://www.atilf.fr./tlfi. 
Walkiewicz B., 2015, Przekład z dyskursywnego punktu widzenia, [w:] S. Niebrzegowska-Bartmińska, M. Nowosad-Bakalarczyk, T. Piekot (red.), Działania na tekście. Przekład - redagowanie - ilustrowanie, „Czerwona Seria” Instytutu Filologii Polskiej UMCS 35, Lublin, s. 45-58.

Witosz B., 2016, Czy potrzebne nam typologie dyskursu?, [w:] B. Witosz, K. Sujkowska-

-Sobisz, E. Ficek (red.), Dyskurs i jego odmiany, Katowice, s. 22-29.

\section{Metalinguistics Operations on a Bilingual Person's Text Summary}

The paper presents the traces of metalinguistic operations reflected in the process of translation into Polish (L2) performed by Zygmunt Krasiński, of two audiences in 1857 and 1858, that the Polish-French bilingual author had with Emperor Napoleon III. Both audiences concerned the so-called Polish cause, la cause polonaise. They constituted a spoken discourse co-created by both participants of those communicative events, and their common code was the French language (L1). Napoleon III demanded strictly confidential audiences, however Krasiński, thanks to his outstanding bilingual competence, transferred the spoken discourse he memorized in extenso in L1, into the sphere of the Polish language (L2). The translations of the audiences, written down in statu nascendi, reveal the process of emergence of the target text in the genre of linguistic mediation. This process included the act of consolidating in Krasiński's memory of a series of replies uttered in L1, and then the act of their translation, recording in L2 in the form of a text that is semantically equivalent to source dialogues. The translation of Napoleon III's words, foreign words, and the auto-translation of Krasiński's own words reflect metalinguistic operations which result from his bilingualism, i.e. from the fact that both French and Polish were his first languages. Metalinguistic operations result from interpretative relations that can occur between two languages which both inhabit the mind of a bilingual person, so that one language becomes the metalanguage for the other one. Krasiński realized the translations exactly as bilingual speech which contains explicit traces of his metalinguistic operations. They take the form of code switching, double language thinking, interference, and negotiation of common meanings in the situation where linguistic units of $\mathrm{L}_{1}$ and $\mathrm{L}_{2}$ differ. The translation of the audiences shows translation as a special type of Krasiński's communication with the Polish national community: the transcript made them available to Polish recipients who did not know the French language. Simultaneously, Krasiński's translation excluded from among potential recipients the speakers of French, as Polish was a language unknown to French elites in the $19^{\text {th }}$ century, and in a sense was a secret language for them.

\section{Les opérations métalinguistiques sur le texte d'une personne bilingue Résumé}

L'article présente les traces d'opérations métalinguistiques qui apparaissent dans le processus de traduction en langue polonaise (L2) de deux audiences qu'effectua Zygmunt Krasiński. Ces audiences furent menées en 1857 et 1858 ; les participants en étaient l'empereur Napoléon III et Krasiński lui-même, écrivain bilingue, polonais et français. Elles concernaient la Cause polonaise. Le code commun du discours oral des deux participants fut la langue française (L1). Napoléon III exigea que ces audiences restent strictement confidentielles. Toutefois, Krasiński, grâce à sa compétence bilingue exceptionnelle, rapporta le discours prononcé en L1 et qu'il avait gardé en mémoire dans son intégra- 
lité dans la sphère de la langue polonaise (L2). La traduction écrite des deux audiences, quasiment dès leur genèse, révèle le processus d'émergence du texte d'arrivée dans la catégorie de la médiation linguistique. Ce processus comprend l'acte de fixer dans la mémoire de Krasiński une série de répliques énoncées en L1, puis celui de les transposer par écrit en L2 tout en constituant un texte sémantiquement équivalent aux dialogues de départ. Dans la traduction des mots d'autrui, ceux de Napoléon III, comme dans l'autotraduction de ses propres mots s'affirment les mécanismes métalinguistiques qui résultent du bilinguisme de l'auteur. Ce fait prouve que le français autant que le polonais étaient les deux langues premières de Krasiński. Les opérations métalinguistiques découlent des relations d'interprétation qui s'établissent entre deux langues coexistant dans l'esprit d'un bilingue de telle sorte qu'une des deux langues peut servir de métalangue à l'autre. Krasiński a réalisé ses traductions précisément au moyen du parler bilingue qui inclut explicitement les traces de ses opérations métalinguistiques. Elles prennent la forme de l'alternance de codes (code-switching), d'une double pensée langagière, d'interférences ainsi que de la négociation de significations communes dans une situation de différence entre les unités linguistiques de la L1 et de la L2. La transposition des audiences en langue polonaise désigne la traduction comme un genre particulier de communication entre Krasiński et la communauté nationale polonaise. Ainsi, grâce à leur traduction écrite les audiences sont-elles devenues accessibles à des destinataires ne connaissant pas la langue française. Mais, dans le même temps, cette traduction excluait les utilisateurs potentiels du français car la langue polonaise étaient une langue inconnue des élites françaises du XIXème siècle; le polonais constituait donc un code secret. 